by Inna Safonoval, Reimar Seltmann ${ }^{2}$, Min Sun $^{3}$, Alfred Kröner ${ }^{4}$, Evgeny Kislov ${ }^{5}$, Victor Kovach $^{6}$, Alan Collins ${ }^{7}$

\title{
Continental Construction in Central Asia (IGCP- 592): Scientific Results and Meetings in 2012
}

\author{
1 Institute of Geology and Mineralogy SB RAS (Siberian Branch of the Russian Academy of Science) Koptyuga prospect 3, Novosibirsk, \\ 630090, Russia. E-mail: \\ 2 Centre for Russian and Central EurAsian Mineral Studies (CERCAMS), Natural History Museum, Cromwell Road, London SW7 5BD, UK \\ 3 Department of Earth Sciences, the University of Hong Kong, Pokfulam Road, Hong Kong, China \\ 4 Institut für Geowissenschaften, Universität Mainz, 55099 Mainz, Germany and Beijing SHRIMP Centre, Chinese Academy of Geological \\ Sciences, No. 26, Baiwanzhuang Road, Beijing 100037, China; \\ 5 Geological Institute SB RAS, 6a Sakhyanova Str., Ulan-Ude, 670047, Russia \\ 6 Institute of Precambrian Geology and Geochronology RAS, 2 Makarova Emb., St. Petersburg, 199034, Russia \\ 7 Tectonics, Resources and Exploration (TRaX), School of Earth and Environmental Sciences, University of Adelaide, Adelaide, SA 5005, \\ Australia
}

IGCP-Project \#592 (2012-2015) "Continental construction in Central Asia”, funded by UNESCOIUGS, was launched in April 2012. The Project focuses on tectonic and magmatic aspects of formation of continental crust in the Central Asian Orogenic Belt and their comparison with actualistic examples from the western Pacific. This report summarizes related scientific results and meetings. In total, in 2012 the Project organized, and/or participated in the organization of, six international conferences and workshops, three of which were accompanied by training schools for young scientists and special training courses. At the present time, more than 250 scientists from 27 countries expressed their interest to collaborate in the frame of our Project, of which more than one third are women and young scientists. Participants come from Australia, Bangladesh, Belgium, Canada, China, Czech Republic, Fiji, Finland, France, Germany, India, Indonesia, Iran, Japan, Kazakhstan, Kyrgyzstan, Mongolia, New Zealand, Poland, Philippines, Republic of Korea, Russia, Tajikistan, Turkey, United Kingdom, USA, and Uzbekistan. In order to carry out research and to secure meeting activities, project participants received funding from national and international sources and mining companies. Below we also present a short overview of meetings scheduled for 2013.

\section{Introduction}

The Central Asian Orogenic Belt (CAOB), one of the largest accretionary orogens on Earth (Fig. 1), has been the focus of international research ever since the innovative publication of Zonenshain et al. (1990), suggesting that the CAOB evolved by accretion of oceanic arcs and/or Gondwana-derived continental blocks to the Siberian, Russian, and North China cratons, and the innovative but provocative publication of Sengör et al. (1993), suggesting that Central Asia evolved from a single, giant island arc in the Palaeozoic and thus represents the largest area of Phanerozoic juvenile crustal growth. The main goal of IGCP Project \#592 is to undertake a broad-scale and multi-method investigation of continental growth and evolution in the $\mathrm{CAOB}$ in order to understand whether the early Phanerozoic was an important period of juvenile continental crust formation or not (e.g., Jahn, 2004; Hawkesworth et al., 2010; Condie and Kröner, 2012; Kröner, et al., in press). The specific goals are linked to four main processes of continental construction: (1) formation of juvenile crust (crustal growth); (2) recycling of continental crust (crustal rejuvenation); (3) continental growth (accretion minus tectonic erosion), (4) continent formation (collisional processes) (Safonova et al., 2011). The research program includes reconstruction of all these processes within individual orogenic belts and across major geological transects such as the Russian Altai Kazakh Altai - Chinese Altai - Mongolian Altai, the Kazakh Tianshan - Kyrgyz Tianshan - Chinese Tianshan, Sayan-Transbaikalia (Russia) - northern Mongolia-southern Mongolia - Inner Mongolia (China), Russian Far East-Japan-Korea. The Project uses an interdisciplinary approach including isotope geochronology, petrology, geochemistry, lithology, sedimentology, micro-palaeontology, tectonics, structural analysis, palaeomagnetism, geophysics, metallogeny and environmental geology. The inferred processes, events and mechanisms of continental construction will be compared with present-day or recent/Quaternary examples from the western and southern Pacific. Another important issue is which social benefits or geohazards are related to the formation of extensive orogenic belts, such as the CAOB including formation of mineral deposits and surface/environmental impacts through volcanism and seismicity. This will finally enable us to reconstruct the entire evolutionary pattern of this huge orogenic system.

The Project arose from the 2010 International Workshop on 


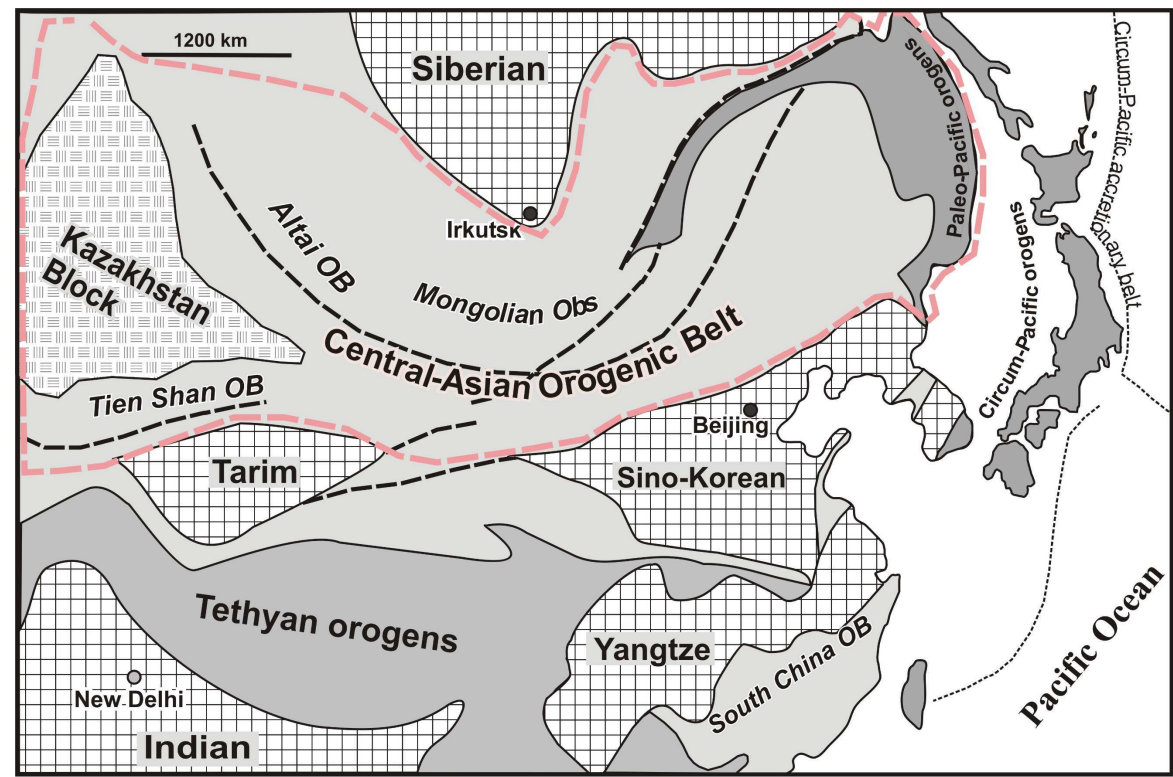

Orogenic regions formed after the closure of paleo-oceans:

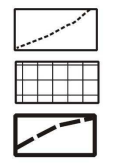

\section{Present subduction}

Cratonic blocks with

Precambrian basement

Main sutures of the $\mathrm{CAOB}$

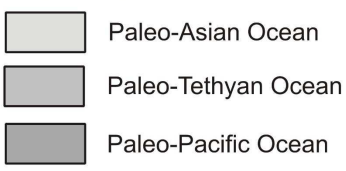

Fig. 1. Simplified tectonic scheme of Central and East Asia showing the main orogens formed after the closure of paleo-oceans and approximate location of local orogenic belts $\mathrm{OB}$, (modified from Ren et al., 1999 and $\mathrm{Li}, 2006$ ). Red dotted line indicates $\mathrm{CAOB}$.

in 2012 (Australia, Belgium, Canada, China, Czech Republic, France, Germany, India, Iran, Japan, Kazakhstan, Kyrgyzstan, Mongolia, New Zealand, Nigeria, Poland, Philippines, Republic of Korea, Russia, Tajikistan, Turkey, United Kingdom, USA, Uzbekistan). All material related to project performance (original application, flyers, circulars, pdf-files of meeting proceedings, photo reports, sponsors, etc.) are available at our website: https:// sites.google.com/site/igcp592/home.

\section{Main Scientific Results}

According to the initial concept IGCP-592 research activities in 2012 concentrated on four main topics: (a) isotopic dating of granitoids and evaluation of juvenile versus recycled crust, based on geochemical and isotopic studies (e.g., Kröner et al., 2012, in press; Xu et al., in press; Song et al., in press; The $6^{\text {th }}$ Siberian, 2012); (b) contribution of accretionary processes and intra-plate magmatism to continental evolution (e.g., Safonova et al., 2011; Biske et al., 2012; Safonova and Santosh, in press; Collins, 2012); (c) mineral deposits related to $\mathrm{CAOB}$ continental evolution (e.g., Kislov, 2012; Dolgopolova et al., 2013; Box et al., in press).

"Geodynamic evolution, tectonics and magmatism of the Central Asian Orogenic Belt", organized by the Institute of Geology and Mineralogy SB RAS in Novosibirsk (Safonova and Buslov, 2010) and the 2011 Penrose Conference "Comparative evolution of past and present accretionary orogens: Central Asia and the Circum-Pacific", organized by the Institute of Geology and Geophysics, Chinese Academy of Sciences, Beijing, and held in Urumqi, NW China (http://www.geosociety.org/gsatoday/archive/22/3/pdf/i1052-5173-22-3-16.pdf). The 2010 conference focused on major ideas and recent advances in CAOB magmatism and tectonics, and the Penrose Conference discussed new data on the $\mathrm{CAOB}$ in comparison with modern accretionary terranes in the Circum-Pacific. During Penrose-related discussions it became apparent that Japan is not the only possible model for the evolution of Central Asia, but areas such as Indonesia and the southern Pacific should also be considered (e.g., Collins, 2002; Metcalfe, 2011; Kröner et al., in press).

In its launch year, IGCP\#592 was involved as co-organizer/cosponsor of six international meetings. This approach secured a headstart for the Project and attracted many participants, especially young scientists and scientists from Developing Countries, and provided an opportunity to promote the major goals of our project, i.e. the role of Gondwana-derived terranes in the CAOB, juvenile versus recycled crust, and a comparison with the Western Pacific. These questions were discussed by researchers who actually work with relevant objectives at localities of true Gondwana terranes (India, Australia, South America) and the western Pacific (Indonesia, Tasmania, Japan). The 2012 meetings focused on both basic research and socially important issues, e.g., formation and exploration of mineral deposits. In this report we focus on our main scientific results, and we review the most important meetings and future plans. In total, participants from 25 countries joined IGCP\#592 related meetings and field visits
The main results were obtained on a variety of topics through cooperative efforts involving many scientists. Kröner et al. (2012, 2013) showed that the Kyrgyz North Tianshan in the southwestern CAOB consists predominantly of reworked Precambrian crustal material, and that zircon dating must therefore be combined with geochemistry as well as $\mathrm{Nd}$ and $\mathrm{Hf}$ isotopes to elucidate source characteristics. Another study along the Kyrgyz-Chinese Tienshan transect showed that the direction of motion and the age of deformations in this foldbelt were similar along its entire length and resulted from the main collisional phase in the Tienshan (Biske et al., 2012). The early-middle Palaeozoic phase in the evolution of the eastern CAOB was dominated by a double subduction-collision accretionary process as proposed for the southern and northern orogenic belts of Inner Mongolia (Xu et al., in press). The Beishan orogenic collage in the southern $\mathrm{CAOB}$ was shown to be a longlived accretionary belt that was continuously active from the late Neoproterozoic into the Palaeozoic, and provides a perfect example for shedding light on its accretionary versus microcontinental architecture (Song et al., in press). Several accretionary belts in the CAOB include accreted oceanic lithosphere or ocean plate stratigraphy (OPS) with ocean rises, which also contributed to continental growth because their volume may have reached that of modern Europe, and their accretion may have forced accumulation of forearc sediments (Safonova et al., 2012; Safonova and Santosh, in press). Important contributions to the study of mineral deposits were made for porphyry deposits in Mongolia where isotopic data showed that their host magmas may have originated from juvenile sources within a subduction-related setting (Dolgopolova et al., 2013; Box et al., in press). The formation of PGE-Ni mineral deposits was reconstructed on the basis of detailed geological studies and up-to-date petrologic modelling (Kislov, 2012). 


\section{IGCP\#592 related meetings in 2012}

The 2012 program included six meetings: (1) International Workshop "Geodynamic evolution of the Central Asian Orogenic Belt", May 25-27, Sankt-Petersburg, Russia; (2) $6^{\text {th }}$ Siberian Conference for Early Career Geoscientists, June 9-23, Novosibirsk, Russia; (3) Symposium 9.7 "Mineral deposits: episodes, accumulation of metals and related geodynamic processes in China and adjacent regions" at the $34^{\text {th }}$ International Geological Congress, August 5-10, Brisbane, Australia; (4) IV International Conference and III Early Career Geoscientists Workshop "Ultramafic-mafic complexes of folded regions and their mineral resources", August 27-30, Ulan-Ude - Baikal, Russia; (5) 2012 IAGR (International Association for Gondwana Research) and IGCP\#592 Symposium on "Gondwana to Asia", November 18-21, Adelaide, Australia; 6) "Chinese-Russian seminar on the Central Asian Orogenic Belt" for young scientists from Novosibirsk State University and The University of Hong Kong, December 4, Hong Kong, China. As more important scientific events we highlight those in Sankt-Petersburg, Ulan-Ude, which was accompanied by early career scientists training school and field visits, and that in Adelaide, where the program included a training seminar and two field trips.

\section{Opening Meeting: International Workshop "Geo- dynamic evolution of the Central Asian Orogenic} Belt"

As mentioned above, IGCP\#592 partly evolved from ideas discussed at the 2011 Penrose Conference, which was limited to 60 participants, and it was thus not possible for many Russian scientists to participate. Therefore, a meeting, supported by IGCP\#592, was held in St.-Petersburg, Russia, in May 2012, organized by the Institute of Precambrian Geology and Geochronology, Russian Academy of Sciences (RAS). The purpose was to discuss recent advances by Russian scientists in southern Siberia, the Russian Altai, Kazakhstan, Primorje (Russian Far East) and Kyrgyz Tienshan areas which are not so well known from the western literature, and by other scientists from Europe and Central Asia.

Important results of the meeting (Kotov and Kovach, 2012) were that $\mathrm{CAOB}$ evolution began as early as latest Mesoproterozoic, that modern-type tectonic elements such OPS, oceanic islands/seamounts/ plateaus, and blueschist-decorated suture zones are well preserved in the Siberian part of the CAOB and that crustal reworking was an important element during orogenesis, implying that crustal growth was not as high as previously suggested. On the other hand, vast territories of the CAOB, e.g., the Lake zone in Mongolia and AltaySayan-Tuva region, include many juvenile crust units, such as island arc complexes and related granitoids (Kovach et al., 2011; Kotov and Kovach, 2012). Other topics for discussion were palaeogeographic reconstructions, the possible role of plumes in the generation of magmatic rocks and Cathasia versus Primorje (Russian Far East) origin of the Japanese islands (Jahn et al., 2012).

The project's board meeting aimed (i) to discuss and agree on future plans and milestones (field research, scientific meetings), (ii) to provide an IGCP592-based forum for discussions on the CAOB, (iii) to stimulate international and interdisciplinary collaboration. The topics of the meeting were concentrated on southern Siberia, Kazakhstan, Altai and Tianshan. The main outlines were: (a) Precambrian-early Palaeozoic evolution; (b) tectonic settings of magmatism, metamorphism and sedimentation in space and time; (c) role of intra-plate magmatism; (d) formation of juvenile versus recycled continental crust; (e) palaeomagnetism and palaeogeodynamic reconstructions of the $\mathrm{CAOB}$ and adjacent cratons. The meeting brought together leading and young scientists from Belgium,

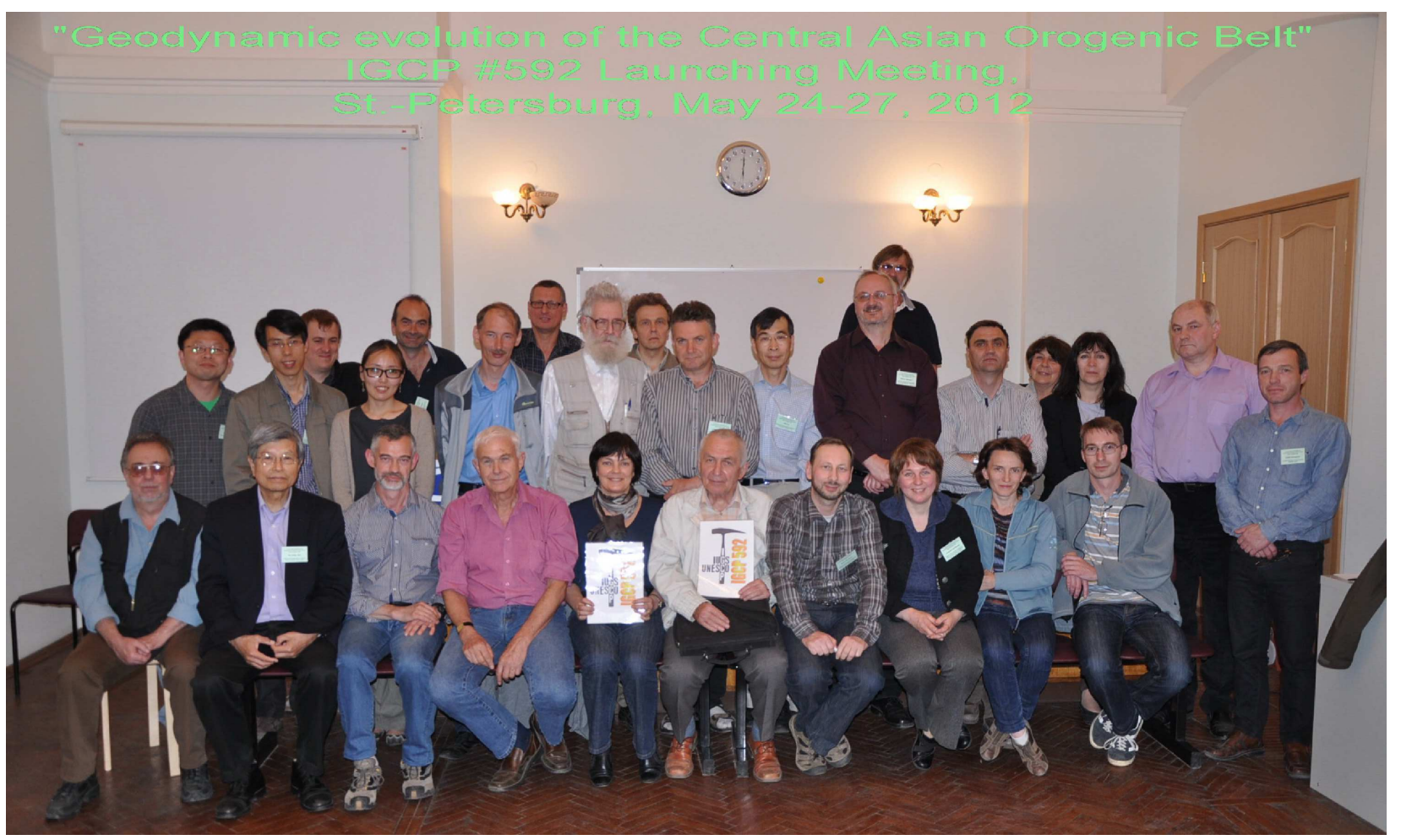

Fig. 2. Participants of the International Workshop "Geodynamic evolution of the Central Asian Orogenic Belt”, May 24-27, 2012, SanktPetersburg, Russia. Venue: Institute of Precambrian Geology and Geochronology, Russian Academy of Sciences. 
China, France, Germany, Mongolia, Russia, Spain, Tajikistan, and United Kingdom (more than 50 participants; Fig. 2). The program included 34 oral presentations as well as discussion of IGCP\#592 plans for 2013-2015. The participants reported new approaches and methods of studying aspects of the formation and evolution of the CAOB (Kotov and Kovach, 2012). The leading research teams from Asia and several western countries agreed on future interdisciplinary collaboration. The project leaders and participants also agreed that future research activities of IGCP\#592 should focus on the following problems: (i) proportion of Phanerozoic versus Precambrian rocks in the CAOB; (ii) what proportions of $\mathrm{CAOB}$ continental crust are juvenile versus recycled; (iii) magmatic arcs or Gondwana-derived terranes or both were accreted to the Siberian, Kazakhstan, Tarim and North China cratons; (iv) the balance between accretionary continental growth and tectonic erosion based on modern examples from the Western Pacific; (v) mineral deposits related to different stages of continental construction. Finally, the participants elaborated on a tentative plan for 2013-2015 that included meetings and field trips in Russia (Transbaikalia, Ural region, Altai), China (Beishan), Korea (Daejeon, Okcheon belt), Kazakhstan (Almaty-Oskemen), Indonesia (Bali), Japan (Tokyo-Gifu), and New Zealand (South Island).

\section{IV international conference and III workshop for early career scientists "Ultramafic-mafic complexes in foldbelts and their mineral resources"}

The meeting program included papers on mafic-ultramafic complexes of the CAOB with focus on (1) geology and tectonics; (2) petrology, mineralogy and geochemistry; (3) isotope geochemistry; (4) contact zones around ultramafic-mafic intrusions and their related mineralization; (5) experimental and digital petrologic modelling; (6) ore mineralization and rock petrogenesis; (7) prospects for PGE-Ni-S mineralization; (8) properties of PGE minerals. The talks were grouped into four sessions: (i) geology, tectonic setting and geodynamic reconstruction of ultramafic-mafic complexes, (ii) petrology and geochemistry of ultramafic-mafic complexes and formation of their related ore mineralization; (iii) PT-conditions and fluid regimes of ore mineralization and their relation to mantle sources; (iv) search, exploration and prospects of mineral deposits related to ultramafic-mafic complexes. The program included a 7-day field training camp at the Yoko-Dovyren PGE-bearing massif and an enroute field excursion to the Oshurkovo apatite-bearing alkaline massif (Fig. 3). The Yoko-Dovyren layered dunite-troctolite-gabbro massif is located north of Lake Baikal and represents a $26 \mathrm{~km}$ long and $3.5 \mathrm{~km}$ wide sill-like body hosted by Neoproterozoic carbonateclastic metasediments. The massif consists of ultra-mafic, layered, and gabbro zones. Economic $\mathrm{Ni}-\mathrm{Cu}$ - sulphide disseminated and massive mineralization is confined to plagio-peridotites, whereas low-sulphide PGE mineralization is confined to the gabbro zone.

Oral and poster presentations were followed by animated discussions on two major issues: (1) links between petrogenesis and ore formation; (2) validity of geological versus physico-chemical basis for petrologic modelling. A special achievement of the meeting was a significant number of papers on metallogeny, ore formation and chromite, $\mathrm{Cu}-\mathrm{Ni}$ and PGE mineral resources as well as contributions presented by graduate students and young scientists. The conference proceedings volume includes 60 papers (Kislov,
2012). The meeting issued a resolution (i) to promote the study of physico-chemical and geological aspects of formation of ultramafic and mafic rocks and related mineral resources; (ii) to publish information about meeting results in the mass-media and on the websites of the Geological Institute in Moscow (GIN RAS), Geological Institute in Ulan-Ude (GIN SB RAS) and IGCP \#592; (iii) to support the Institute of Geology and Mineralogy SB RAS and Novosibirsk State University, both in Novosibirsk, to organize the $5^{\text {th }}$ meeting in 2015, at the Shira Geology Field Training Ground in the Khakasia Region; (iv) to organize and promote field training courses for young scientists. This meeting gave Russian scientists an opportunity to learn about the Project and to appreciate the link between IGCP\#592 and the formation of PGE-Ni mineral deposits in relation to intra-plate magmatism, folding, and other processes of continental evolution.

\section{The 2012 IAGR and IGCP 592 Annual Convention and $9^{\text {th }}$ International Symposium on "Gondwana to Asia"}

The meeting program included (i) oral and poster presentations in five sessions, namely Gondwana Resources, Gondwana Amalgamation, Gondwana Breakup and the Amalgamation of Asia, Continental construction in Central Asia (IGCP\#592); (ii) pre- and post-conference field trips; (iii) GPlates Training Workshop; (iv) Annual Meeting of the Gondwana Research (GR) Editorial Board and International Association of Gondwana Research (IAGR) Secretariat. The objective of the pre-conference field trip was to examine the deformation and magmatism associated with initial Cambrian Pacific subduction in the Delamerian Orogen (Fig. 4). The objective of the post-conference field trip was the Palaeoproterozoic Kalinjala Shear System in the eastern Gawler Craton. About 100 participants from Australia, Brazil, China, Germany, India, Iran, Japan, New Zealand, Nigeria, Russia, South Africa, South Korea, Turkey and UK presented 40 oral and 30 poster contributions. The GR-IAGR meeting discussed the annual results of GR and IAGR activity. The participants of the G-Plates Training Workshop used plate reconstruction software for Gondwana assembly/breakup modelling. The participants of the pre-conference field excursion observed synto post-tectonic granitoids and foreland thrust-and-fold belt deformation resulting in the formation of the Delamerian Orogen. The participants of the post-conference field excursion examined the structural and metamorphic architecture of the Kalinjala Shear Zone and examined lower crustal high-strain granulites, coarse-grained metasedimentary rocks, and deformed granitic units intruded by mafic dykes. Two abstract volumes included 38 oral and 26 poster presentations. The hottest discussions were on palaeotectonic reconstructions of Gondwana and on the presence on Gondwanaderived continental blocks in orogenic belts, e.g., in the CAOB, the target of IGCP\#592. Scientific contributions covered all continents as well as orogenic processes in the regions. The Organizing Committee proposed to organize special issues in the Chinese journal Geoscience Frontiers and the Journal of Asian Earth Sciences. The IAGR Annual Meeting agreed on the 2013 symposium to be held in South Korea. This meeting helped IGCP\#592 to promote the major goals of the project, i.e. the role of Gondwana-derived terrains in the $\mathrm{CAOB}$, juvenile versus recycled crust in the $\mathrm{CAOB}$, and a comparison with the Western Pacific. 

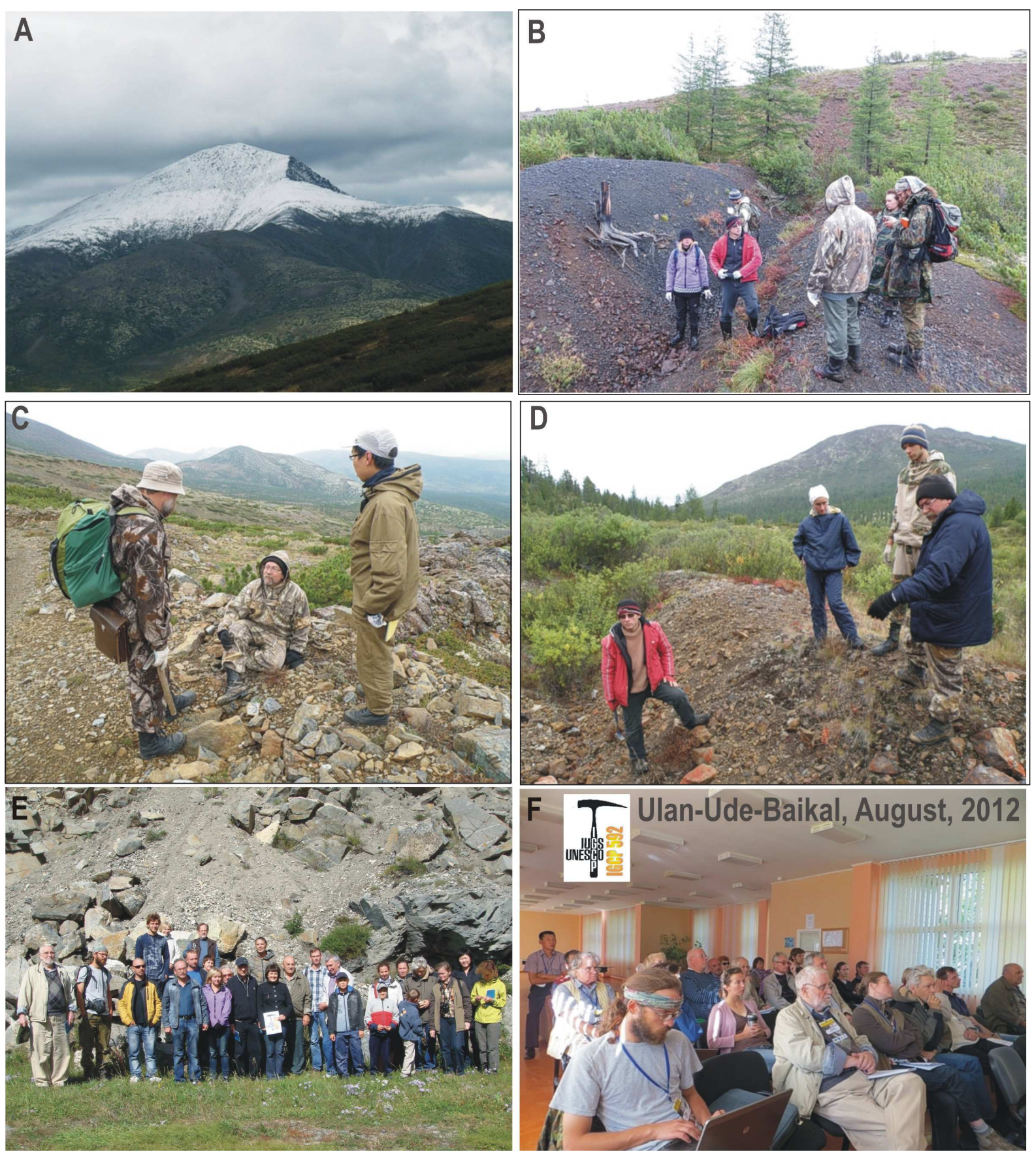

Fig. 3. Photo report for the IV International conference and III Field Training school-seminar for early-career geoscientists "Ultramaficmafic complexes of folded regions and its minerageny"; Ulan-Ude - Lake Baikal, August 17-31, 2012. A - Ty'ya Mt. composed of volcanic rocks coeval to the Dovyren PGE-bearing mafic-ultramafic massif; B - young scientists exploring outcrops of the Dovyren massif; $C$, $D$ Prof. Evgeny Kislov explaining to young scientists the history of the Dovyren massif; E-group photo at the Oshurkovo apatite-bearing alkaline massif; $\boldsymbol{F}$ - conference session.

\section{Social benefits}

The social benefits of the Project are related to mining geology, mineral resources, environmental studies and training of students and young scientists. Project activities contributed to better prospecting and exploration of mineral deposits through better understanding of their formation and evolution in relation to continental evolution processes (Anonymous, 2012a,b; Kislov, 2012; Dolgopolova et al., 2013) and environmental impact (Krivonogov et al., 2012). Young scientists and students actively participated in many project activities, especially during the meetings in Novosibirsk, Ulan-Ude and Hong Kong. The early carrier geoscientists meetings in Novosibirsk and Ulan-Ude (Russia) included field training sessions in the Kurai subduction-acccretionary complex in the Russian Altai and at the Dovyren PGE-Ni-bearing massif of Transbaikalia, respectively. The workshop in Hong Kong was held under the auspices of IGCP\#592 and included an exchange of recent theoretical and analytical results on the $\mathrm{CAOB}$.

In addition, to young scientists, several participants from Developing Countries and women attended our meetings. The 


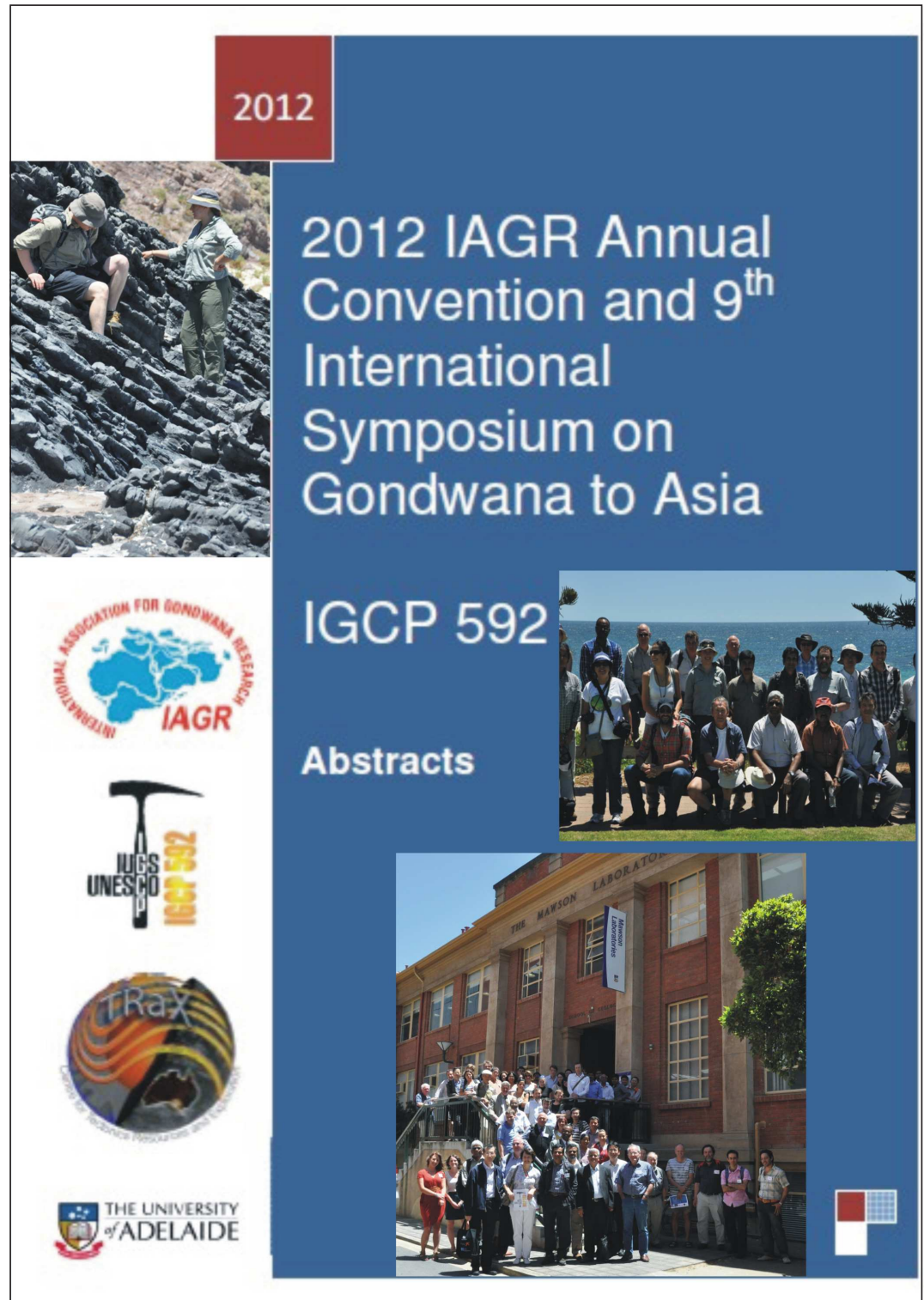

Fig. 4. Abstract volume cover sheet of the 2012 IAGR Annual Convention and $9^{\text {th }}$ International Symposium on "Gondwana to Asia" with juxtaposed group photos taken during the post (uppermost) and pre-conference (medium left and lower) excursions and symposium sessions (medium right).

geographic position of the major areas of interest, which all are in Central and Eastern Asia, determined the high portion of project participants from developing countries, namely, China, Kazakhstan, Kyrgyzstan, Mongolia, Russian Federation, Tajikistan, Uzbekistan, on average about $80 \%$ of a total of 350 participants of IGCP\#592related meetings. Among these about $15 \%$ were female scientists and $30 \%$ were young scientists. Project funding was distributed among these three categories of scientists.

\section{Activities planned}

Future activities of the project will be aimed (i) to link the bordering geological structures along the transects that cross the Kazakh-Russian-Chinese-Mongolian Altai and the Kyrgyz-KazakhChinese Tienshan through detailed mapping, rock sampling, and highprecision major and trace element analysis; (ii) to identify elements of Oceanic Plate Stratigraphy (OPS) in accretionary complexes in order to understand how accretion contributed to continental growth; (iii) to analyse $\mathrm{Nd}$ whole-rock and $\mathrm{Hf}$ isotopes in magmatic and detrital zircons from granitoids, turbidites and modern sediments in order to evaluate the proportion of juvenile and recycled crust in the $\mathrm{CAOB}$; (iv) to study geodynamic controls of horizontal and vertical accretion towards a better understanding of crust-mantle interaction during ore-forming processes in accretionary orogens and intraplate settings and interconnection of both; (v) to evaluate the contribution of intraplate magmatism to crustal growth and the formation of minerals deposit.

We plan the following conferences and field trips for 2013-2014 to be organized and held under the auspices of IGCP\#592 "Continental Construction in Central Asia".

1. The $2^{\text {nd }}$ International Symposium and Training School for Young Scientists "Continental Rifting and its Related Processes”, August 20-23, 2013, Irkutsk, Russia. This meeting will focus on Cenozoic rifting in Central and East Asia which was accompanied by volcanism, hydrothermal activity, tectonic movement, sedimentation, and formation of oil-andgas and other metalliferous mineral deposits. The symposium will highlight problems of Cenozoic rifting and its linkage with the entire geological history of the continent and involve participation of university, academic and ministry under- and postgraduate students and researchers from mining companies.

2. Field trip and meeting "Beishan Orogen in NW China: accretionary tectonics, magmatism, eclogites and granulite complexes", August 22-28, 2013, Dunhuang-Hami, NW China. This will be our key meeting, organized to study a key accretionary orogen of the $\mathrm{CAOB}$ and to compare it with other accretionary belts in the $\mathrm{CAOB}$ and the modern Pacific. The Beishan Orogen connects the Southern Tianshan suture to the west and the Solonker suture in Chinese Inner Mongolia to the east. Its tectonic evolution is crucial for understanding the history of the southern Altaids. The topics of the workshop will be (1) Geology of NW China: Introduction to the field trip; (2) Progressive accretionary tectonics and temporal-spatial characteristics of the southern Altaids; (3) Supra-subduction magmatic units: lithology, geochemistry and petrology; (4) Geological implications of eclogite and granulite complexes. Scientific sessions: (1) accretionary structures and subductionrelated magmatism; (2) geological implications of eclogites and granulites; and (3) accretionary tectonics and temporal-spatial characteristics of the southern Altaids. The field trip will include observations of (1) Xingxingxia shear zone; (2) Hongyanjing superposed fold; (3) Qijiaojing-Pochengshan thrust belt; (4) Gubaoquan eclogites; (5) Liuyuan adakite, Nb-enriched basalt, granitoids; (6) Guazhou granulite and gneissic terranes.

3. 2013 IAGR Annual Convention and $10^{\text {th }}$ International Symposium on "Gondwana to Asia", October 1-4, KIGAM, Daejeon, South Korea. The symposium will be devoted to cutting- 
edge stories on Gondwana as well as a field trip to an amalgamated block (Korea) fragmented off Gondwana. Focus will be on a comparison of continental construction features in Central Asia with those of the western Pacific and on the foldbelts of South Korea resulting in the amalgamation of the North and South China Cratons. The symposium will be followed by a 2-day field trip to the Hongseong eclogite site and Imjingang collisional belt.

4. Meeting and field trip "Mesozoic Orogen of New Zealand"; to be organized by the Geological Society of New Zealand and IGCP\#592, November 24 - December 3, 2013. The IGCP\#592 session of this meeting will be devoted to a comparison between the Mesozoic accretionary orogen of the South Island and accretionary orogens of the CAOB. During the post-conference field trip participants will see sedimentary and volcanic rocks of New Zealand's Permian-Jurassic Eastern Province accretionary and forearc terranes, the structural and metamorphic overprint of the Jurassic-Cretaceous Otago Schist on the Caples and Rakaia Terranes, and parts of the Carboniferous to Cretaceous Median Batholith and Late Cretaceous-Miocene cover strata and Miocene intraplate volcanics. More detailed information about the planned meetings (circulars, flyers, etc.) is available at https://sites. google.com/site/igcp592/milestone-meetings.

\section{Acknowledgements}

We thank project participants for attending IGCP\#592-related meetings and sharing their knowledge about the $\mathrm{CAOB}$ and western Pacific with colleagues elsewhere. Furthermore, thanks are due to the following funding institutions (in alphabetical order): Basic Research Project no. GP-2012-004 of Korea Institute of Geoscience and Mineral Resources (Republic of Korea), Beijing SHRIMP Center (China), Brain Pool Program of the Korea Foundation for Science and Technology (Republic of Korea), Centre for Russian and Central EurAsian Mineral Studies (CERCAMS) of the Natural History Museum of London (UK), China Geological Survey Projects, Chinese National Basic Research 973 Program, Hong Kong Research Grant Council, Hong Kong University, German Science Foundation (DFG), Institute of Geology and Mineralogy SB RAS (Novosibirsk, Russia) research projects, Institute of Precambrian Geology and Geochronology RAS (St.-Petersburg, Russia), International Union of Geosciences (IUGS), KASKAD Industrial-Technological Centre (Russia), Ministry of Education, Culture, Sports, Science and Technology of Japan, National 305 Project of China, National Natural Science Foundation of China, Novosibirsk State University (Russia), Siberian and Far-East Branches of the Russian Academy of Sciences, Russian Foundation for Basic Research (RFBR), Science Research GeoTechnology Center of Vladivostok (Russia), UNESCO.

\section{References}

Anonymous, 2012a, The $6^{\text {th }}$ International Siberian Early Career GeoScientists Conference. 9-23 June, 2012, Novosibirsk, Russia. Proceedings of the Conference. IGM SB RAS, IPGG SB RAS \& NSU, Novosibirsk, 2012, 313 P.

Anonymous, 2012b, Proceedings of the 34th International Geological Congress 2012. ISBN 978-0-646-57800-2. CD-ROM.

Baksheev, I.A., Plotinskaya O.Yu., Yapaskurt, V.O., Vigasina, M.F., Bryzgalov, I.A., Groznova, E.O., and Marushchenko, L.I., 2012, Tourmaline from Deposits of the Birgil'da-Tomino Ore Cluster,
South Urals: Geology of Ore Deposits, v. 54, pp. 458-473.

Biske, Yu.S., Alexeiev, D. V., Wang, D., Wang, F., Getman, O.F., Jenchuraeva, A.V., Seltmann, R., and Aristov, V.A., 2012, Structures of the Late Paleozoic Thrust Belt in the Chinese South Tian Shan: Doklady Earth Sciences, v. 442, pp. 8-12.

Box, S.E., Syusyura, B., Seltmann, R., Creaser, R.A., Dolgopolova, A., and Zientek, M.L., in press, Dzhezkazgan and associated sandstone copper deposits of the Chu-Sarysu Basin, Central Kazakhstan. In: Geology and Genesis of Major Copper Deposits and Districts of the World: A Tribute to Richard H. Sillitoe. Society of Economic Geologists, Inc. Special Publication 16.

Collins, A. (Ed.), 2012, The 2012 IAGR Annual Convention and $9^{\text {th }}$ International Symposium on Gondwana to Asia. IGCP 592: Abstracts (18-21 November 2012, Adelaide, Australia). University of Adelaide Publ., 81 p.

Collins, W.J., 2002, Hot orogens, tectonic switching, and creation of continental crust: Geology of Ore Deposits, v. 30, pp. 535-538.

Condie, K.C. and Kröner, A., 2012, The building blocks of continental crust: Evidence for a major transition in tectonic regime at the end of the Archean: Gondwana Research, v. 23, pp. 394-402.

Dolgopolova, A., Seltmann, R., Armstrong, R., Belousova, E., Pankhurst, R.J., and Kavalieris, I., 2013, Sr-Nd-Pb-Hf isotope systematics of the Hugo Dummett $\mathrm{Cu}-\mathrm{Au}$ porphyry deposit (Oyu Tolgoi, Mongolia): Lithos, v. 164-167, pp. 47-64.

Kotov, A.B., Kovach, V.P. (Eds.), 2012, International Workshop "Geodynamic evolution of the Central Asian Orogenic Belt", 2328 May, 2012, Institute of Precambrian Geology and Geochronology RAS, Sankt-Petersburg, Russia, Abstracts CD-ROM.

Hawkesworth, C.J., Dhuime, B., Oietranik, A.B., Cawood, P.A., Kemp, A.I.S., and Storey, C.D., 2010, The generation and evolution of the continental crust: Journal of the Geological Society, London, v. 167, no. 2, pp. 229-248.

Jahn, B.-M., 2004. The Central Asian Orogenic Belt and growth of the continental crust in the Phanerozoic, in Malpas, J., Fletcher, C. J. N., Ali, J. R., Aitchison, J. C., eds., Aspects of the tectonic evolution of China: Geological Society, London, Special Publication, v. 226, pp. 73-100.

Jahn, B.-M., Usuki M., Ishihara, S., and Okamoto, K., 2012, Major distinction between the accretionary orogens in SW and NE Japan (Hokkaido included): geochemical arguments and implications for crustal growth. Abstract-CD of the $1^{\text {st }}$ International Workshop on the Geodynamic Evolution of the Central Asian Orogenic Belt, May 25-27, St. Petersburg. Institute of Precambrian Geology and Geochronology, Russian Academy of Sciences (www.ipgg.ru).

Kislov, E.V. (Ed.), 2012, Ultramafic-mafic complexes of foldbelts and their mineral deposits: Proc. IV International Conference and III Early Career Workshop (August 25-30, 2012, Ulan-Ude, Russia). Ekos, Ulan-Ude, 212 p.

Kovach, V.P., Yarmolyuk, V.V., Kovalenko, V.I., Kozlovskyi, A.M., Kotov, A.B., and Terent'eva, L.B., 2011, Composition, Sources, and Mechanisms of Formation of the Continental Crust of the Lake Zone of the Central Asian Caledonides. II. Geochemical and Nd Isotope Data: Petrology, v. 19, pp. 399-425.

Krivonogov, S.K., Yi, S., Kashiwaya, K., Kim, J.C., Narantsetseg, T., Oyunchimeg, T., Safonova, I.Y., Kazansky, A.Y., Sitnikova, T., Kim, J.Y., and Hasebe, N., 2012, Solved and unsolved problems of sedimentation, glaciation and paleolakes of the Darhad Basin, Northern Mongolia: Quaternary Science Reviews, v. 56 , pp. $142-163$. 
Kröner, D.V. Alexeiev, Hegner, E., Rojas-Agramonte, Y., Corsini, M., Chao, Y., Wong, J., Windley, B.F., Liu, D., and Tretyakov, A.A., 2012, Zircon and muscovite ages, geochemistry, and NdHf isotopes for the Aktyuz metamorphic terrane: evidence for an Early Ordovician collisional belt in the northern Tianshan of Kyrgyzstan: Gondwana Research, v. 21, pp. 901-927.

Kröner, A., Alexeiev D.V., Rojas-Agramonte, Y., Hegner, E., Wong, J., Xia, X., Belousova, E., Mikolaichuk, A.V., Seltmann, R., Liu, D., and Kiselev, V.V., 2013, Mesoproterozoic (Grenville-age) terranes in the Kyrgyz North Tianshan: Zircon ages and Nd-Hf isotopic constraints on the origin and evolution of basement blocks in the southern Central Asian Orogen: Gondwana Research, v. 23, pp. 272-295.

Kröner, A., Kovach, V., Belousova, E., Hegner, E., Armstrong, R., Dolgopolova, A., Seltmann, R., Alexeiev, D.V., Hoffmann, J.E., Wong, J., M. Sun, Cai, K., Wang, T., Tong, Y., Wilde, S.A., Degtyarev, K.E., and Rytsk, E., in press, Reassessment of continental growth during the accretionary history of the Central Asian Orogenic Belt. Gondwana Research http://dx.doi.org/ 10.1016/j.gr.2012.12.023 .

Li, J.-Y., 2006, Permian geodynamic setting of Northeast China and adjacent regions: closure of the Paleo-Asian Ocean and subduction of the Paleo-Pacific Plate: Journal of Asian Earth Sciences, v. 26, no. 3-4, pp. 207-224.

Metcalfe, I., 2011, Tectonic framework and Phanerozoic evolution of Sundaland: Gondwana Research, v. 19, pp. 3-21.

Ren, J., Wang, Z., Chen, B., Jiang, Ch., Niu, B., Li, J., Xie, G., He, Zh., Liu, Zh., 1999, The tectonics of China from a global view: a guide to the tectonic map of China and adjacent regions. Geological Publishing House, Beijing.

Safonova, I., Buslov, M., 2010, International workshop on geodynamic evolution, tectonics and magmatism of the Central
Asian orogenic belt and pre-workshop field excursion to Gorny Altay, Russia: Episodes, v. 33, no. 3, pp. 205-207.

Safonova, I., Seltmann, R., Kröner, A., Gladkochub, D., Schulmann, K., Xiao, W., Kim, J., Komiya, T., and Sun, M., 2011. A new concept of continental construction in the Central Asian Orogenic Belt (compared to actualistic examples from the Western Pacific): Episodes, v. 34, pp. 186-196.

Safonova, I.Yu., Simonov, V.A., Kurganskaya, E.V., Obut, O.T., Romer, R.L., and Seltmann, R., 2012, Late Paleozoic oceanic basalts hosted by the Char suture-shear zone, East Kazakhstan: Geological position, geochemistry, petrogenesis and tectonic setting: Journal of Asian Earth Sciences, v. 49, pp. 20-39.

Safonova, I.Y., Santosh, M., in press, Accretionary complexes in the Asia-Pacific region: Tracing archives of ocean plate stratigraphy and tracking mantle plumes: Gondwana Research, doi: 10.1016/ j.gr.2012.10.008

Sengör, A.M.C., Natal'in, B.A., and Burtman, V.S., 1993, Evolution of the Altaid tectonic collage and Paleozoic crustal growth in Eurasia: Nature, v. 364, no. 6435, pp. 299-307.

Song, D., Xiao, W., Han, Ch., Li, J., Qu, J., Guo, Q., Lin, L., Wang, $\mathrm{Zh}$., in press. Progressive accretionary tectonics of the Beishan orogenic collage, southern Altaids: Insights from zircon $\mathrm{U}-\mathrm{Pb}$ and Hf isotopic data of high-grade complexes. Precambrian Res., doi: 10.1016/j.precamres.2012.06.011

Xu, B., Charvet J., Chen, Y., Zhao, P., Shi, G., in press. Middle Paleozoic convergent orogenic belts in western Inner Mongolia (China): framework, kinematics, geochronology and implications for tectonic evolution of the Central Asian Orogenic Belt. Gondwana Research, doi:10.1016/j.gr.2012.05.015.

Zonenshain, L.P., Kuzmin, M.I., Natapov, L.M., 1990, Geology of the USSR: a Plate-Tectonic Synthesis, American Geophysical Union, Geodynamic Series, v. 21. 